\title{
Application of Metacognitive Strategies in EFL Writing Instruction
}

\author{
Tianqiong Xia \\ Huaiyin Normal University \\ Huai'an, China
}

\begin{abstract}
English writing, traditionally seen as one of the four basic skills of second language (L2) learning, always plays an important role in language teaching and learning. How to improve students' writing proficiency is one of hot issues in EFL instruction. This paper explores metacognitive strategies application in EFL Writing instruction with an aim to put forward some suggestions for EFL writing instructions.
\end{abstract}

Keywords-metacognition; metacognitive knowledge; learning strategies; metacognitive strategies; writing proficiency

\section{INTRODUCTION}

English writing, traditionally seen as one of the four basic skills of second language (L2) learning always plays an important role in language teaching and learning. It can reflect learners' overall mastery of English language learning. Wen Qiufang (1996) have claimed that English writing ability will become one of the most important criteria for qualified personnel in the 21 st century. Thus students struggle with writing will face significant barriers in education, employment, and other life pursuits. However, writing is not an easy job. It is a complex and recursive process that needs internalizing what one has learned and then producing something new. Producing a coherent, fluent and extended piece of writing requires learners with a rich knowledge of cognitive processes and strategies for planning, text production, and revision. Therefore, writing has been a big headache haunting most second language learners, especially for those studying in a university all the time.

In the second-class college context of China, the fact is that many college students' writing ability is far from satisfaction. After learning English for years, they often fail to compose a piece of writing in English as required. According to relevant statistics, many college students' writing scores have been wandering between 5 points and 7 points (the full score is 15 points) since writing was incorporated into College English Test 4 and 6 (CET-4 and 6) in 1987. Many causes are attributed to the current situation of College English writing in China. On the one hand, the large class size is one of key factors contributing to the inefficiency of writing instruction. The majority of EFL writing teachers in China teach between 30 and 60 students in one writing class. The class size is so large that teachers cannot notice the errors learners make beyond sentence level, not to mention conducting individual conferences with learners, which is believed to be one of the most effective strategies in EFL writing instruction. On the other hand, most students are passive learners. They very often just follow their teachers' rules and fail to think over their own learning behaviors in order to monitor and regulate their cognitive learning. They frequently have limited knowledge about writing process as well as difficulties with cognitive processes and strategies which are believed to be essential for effective writing (Graham and Harris, 2003).

In the face of the present situation, how to improve college students' writing proficiency has got much concern. In the past two decades, many researches have been conducted in the field of writing instruction. In China, previous study has mainly focused on the influential factors in students' EFL writing (Wang Chuming et al. 2000; Wu Jin Zhang Zaixin, 2000; Wang Wenyu, Wen Qiufang, 2002; Wu Hongyun, Liu Ruiqing, 2004; Wu Hongyun, 2006 etc.) and the efficient method to achieve successful EFL writing (ZhaoYongqing, 1995; Chen Huiyuan, 1998; Ma Guanghui, Wen Qiufang, 1999; Lu Wenjun, 2006, Ji Kangli, 2002, etc.).

Metacognition, put forward by American psychologist Flavell in 1970s, is commonly defined as "cognition of cognition". It consists of two parts: metacognitive knowledge and metacognitive strategies. Metacognitive strategy is mainly concerned with planning, monitoring and regulating learning at a macro-level, which has been a focus of research in the field of Second Language Acquisition (SEL) in the past two decades. Previous research has shown that metacognitive strategy can enlighten learners' thinking, improve their self-regulatory abilities and then lead to better learning performance. The research undertaken so far may demonstrate its importance in language learning. O'Malley et al. (1985) has stated, "Students without metacognitive approaches are essentially learners without direction and ability to review their progress, accomplishments, and future learning directions.'(qtd. in O'Malley \& Chamot, 1985: 43). Wu Hongyun (2006) states that both of the important aspects of metacognition involve metacognitive strategies so metacognitive strategy should play its place in metacognition in EFL writing and should exist as an independent element.

However, there are relatively few researches on the application of metacognitive strategy in foreign language writing. In China, direct study of this aspect is limited. How to apply metacognitive strategy to EFL writing, therefore, is far from clear to us. Accordingly, the present research intends to explore the application of metacognitive strategy 
EFL (English as a Foreign Language) writing class and put forward some suggestions to improve students' writing proficiency.

\section{ClassificAtion OF METACOGNITIVE StRATEGIES IN EFL WRITING INSTRUCTION}

Metacognitive strategy, as one category of learning strategies, is generally regarded as methods and rules used by learners to regulate and monitor their cognitive activity, which involves many aspects of learners such as metacognitive, cognitive, social or affective, and can contribute to language learning directly or indirectly. "Learning strategies are problem-orientated, so learners can use a strategy to overcome some particular learning problem" (Ellis, 1994:532). A suitable and effective choice of learning strategies is essential for successful language learning.

O'Malley and Chamot (1985) have developed a somewhat different system of categorization of metacognitive strategies on the basis of the research on the use of learning strategies in second language acquisition and learning, and it is in accordance with the information processing model. They hold that metacognitive strategies are made up of three main parts: planning, monitoring and evaluation, each of which has its subdivisions, as shown in "Fig. 1":

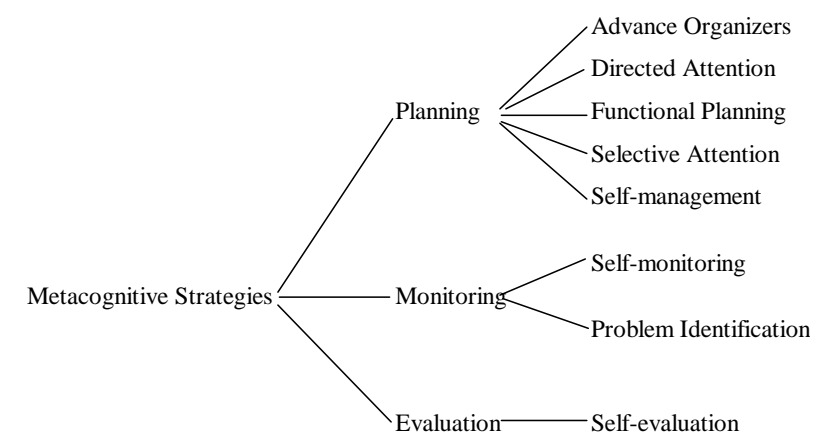

Fig. 1. Categorization of metacognitive strategies.

Here the author concurs with O'Malley and Chamot's classification of metacognitive strategies and thought that the classification was more comprehensive and feasible in the Chinese context. So in the present study the metacognitive strategy instruction for EFL writing is based on O'Malley and Chamot's taxonomy of metacognitive strategies. Here a detailed illustration of their classification is given below:The first category, planning, crucial to language learning because it determines learners' work in subsequent stages, involves five strategies: (1) Advance organization refers to preview the main ideas and concepts of the material to be learned, often by skimming the text for the organizing principle. (2) Directed attention means deciding generally to attend to the learning task and avoid irrelevant distractions. (3) Selective attention involves deciding in advance to notice particular details often by scanning for key words, concepts, and/or linguistic markers.(4) Functional planning means planning for and rehearsing linguistic components necessary to carry out an upcoming language task. (5) Self-management means understanding the conditions that help learners successfully accomplish language tasks and arranging for the presence of those conditions. The conditions here can be interpreted as learners' linguistic and background knowledge as well as physical conditions. The next category, monitoring involves checking, verifying or correcting one's comprehension or performance in the course of a language task. As far as EFL writing is concerned, self-monitoring represents the conscious control and regulation of processes exercised by writers. The core function of monitoring is controlling, directing and sequencing the composing processes as well as one's progress in the task. Furthermore, it enables the writer to make decisions as to whether something needs to be retrieved; whether new ideas have to be further generated; whether a given sub-process has to come to an end, and so on.

Self-evaluation, the last but not the least category, refers to checking the outcomes of one's own language learning against a standard after it has been completed. It mainly subsumes five strategies, namely, evaluation of production, ability, performance, strategy and language. In EFL writing, self-evaluation involves an assessment that the writer makes either of the text produced or of the planned thought. According to Beach (1975), self-evaluation can provide writers with some specific short-term indicators of their abilities to perform a task and enable them to note some consistent changes or improvements in the foreign language writing. Otherwise, students may never have been aware of his writing behavior or changes they had made.

\section{APPLICATION OF METACOGNITIVE STRATEGIES IN EFL WRITING COURSE}

In October 2015, the research was formally unfolded at the beginning of students' first academic year college. Metacognitive strategy instruction was implemented in EFL writing class for 15 weeks.

\section{A. Class Instruction Process}

In order to elaborate the instructional procedure clearly, the researcher has made a detailed description as follows. The classroom instruction is based on O'Malley and Chamot's (1985) and Cohen's (2000) Models for Strategy Training. The whole instruction process is executed and monitored by the author herself. The researcher applied metacognitive strategy to real-life English class and emphasizes the importance of English writing. The strategy instruction (referring to metacognitive strategy instruction) aims at developing students' knowledge in when, why, and how the strategies can be used to promote their writing. The instruction focuses on the following three aspects: (1) increasing students' metacognitive awareness of writing process; (2) helping students setting realistic goals and making learning plans; (3) helping students to make self monitoring and self-evaluation on their writing. The ultimate goal of strategy training is to help students raise metacognitive awareness, develop their self-monitoring and self-coordination ability, thus train students to be independent learners. Simply speaking, the instruction 
intends to make students have a good understanding of the following aspects: why writing metacognitive strategies are useful, and when, where and how to use them through examples.

\section{B. The Main Stages of the Metacognitive Strategy Instruction}

Based on the Chamot's (1985) and Cohen's research (2000), the author has made the metacognitive-operational framework in the present study as shown in "Fig. 2":

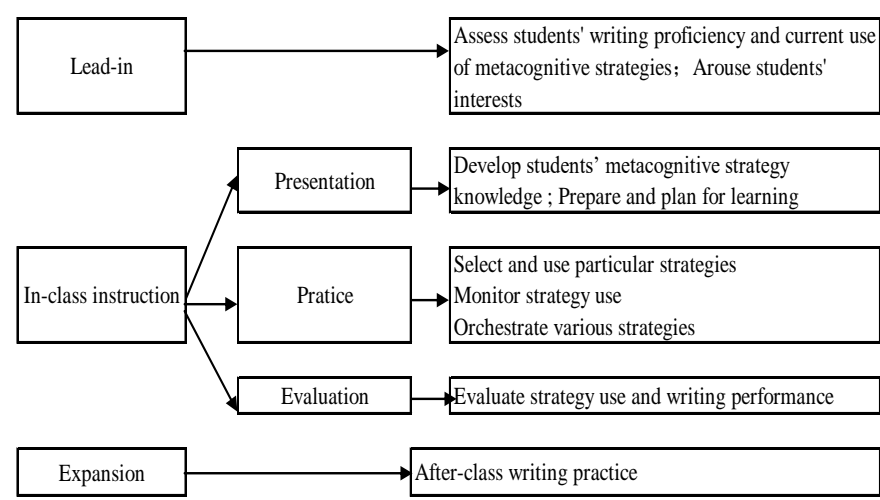

Fig. 2. The Operational Framework of Metacognitive Strategy.

The present classroom instruction is composed of three stages.

1) Lead in: It is the preliminary stage for the next step. As Oxford (1989) states, L2 strategy training should be based clearly on students' attitudes, beliefs, and stated needs. At very beginning, students are asked to complete the Questionnaire of Metacognitive Ability and Metacognitive Strategy Use with the purpose to assess students writing proficiency and current use of metacognitive strategies. By means of Questionnaire filling and explanation, it helps students have a clear idea of their strategy use in their writing and enables students to reflect on their own learning styles, their personalities and their current writing level. Then the students can be well informed in advance why it is necessary for them to attend the instruction. In this way, the students can be motivated to participate in the instruction. That is to say, this phase intends to increase their metacognitive awareness and arouse their interests in the incoming instruction, i.e. having some understanding of the importance of writing, standards of excellent compositions and the purpose of writing, knowing something about the strengths and weakness in the composition of their own after this phase.

2) In-class instruction: The in-class instruction is divided into three stages: presentation, practice and evaluation stage. This stage lasts 12 weeks and in every week there is an instructional focus, and the class arrangement is as follows: the first week centers on "punctuation and capital letters"; the second week "transitional words"; the third week "topic sentences"; the fourth week "well-organized sentences"; the fifth week "cohesion"; the sixth week "overall structure of a composition"; the seventh to tenth weeks "comprehensive practice".

a) Presentation: The focus of this phase is to develop students' metacognitive knowledge and, prepare and plan for writing. Paris and Winograd (1990) emphasize the important role metacognition plays in academic learning, and recommend direct instruction as one effective classroom practice that will help students develop their metacognitive knowledge. They have summarized five key features which teachers should focus their explanations on when they attempt to teach students how to learn metacognitively: What metacognitive strategy is? Why the strategy should be learned? How to use the strategy? When and where the strategy is to be used? How to evaluate the use of the strategy?

Based on the above questions, in the present study the teacher has made an explicit explanation of metacognitive knowledge involving critical characteristics of the strategies, potential benefits of the strategies, and appropriate circumstances under which strategies should be employed. Meanwhile the Metacognitive Questionnaire is used by the teacher as examples to explain to the students the points for successful writing. At end of this period, cue cards made by the teacher are distributed to the individual students and prepare them for the following writing practice. The frequently-used strategies are written on the cards, which were available for students to study as needed. Metacognitive strategies shown in the cue cards see Appendix I.

In conclusion, the purpose of lead-in is to provide explicit explanations on the definition and construct of metacognitive strategy so that the students who used to be subconsciously aware of or most of the time unaware of their own cognitive activities will become metacognitively aware of their mental actions when they perform cognitive tasks. This phase lasts 2 weeks and at end of the phase, the students are supposed to be capable of setting realistic goals in their writing.

b) Practice: At the very beginning of the class, the teacher provides explicit explanations on the definition and construct of metacognitive strategy so that the students become metacognitively aware of their mental actions when they perform cognitive tasks. With proper and full preparation at the presentation stage, students can smoothly move on to the practice stage. The main purpose of this stage is to teach and help learners to participate actively in writing practice and internalize the strategies in their writing. My instruction is based on Vygotsky's (1978) concept of the zone of proximal development and revolves three aspects as follows:

Firstly, to motivate students' interests by making them have a clear idea of writing purposes. O' Malley \& Chamot (1990: 160) states that motivation is probably the most important characteristic that students bring to a learning task. Motivation is a very important component of metacognition. In the present study, the researcher allows students to 
determine the writing topic by group discussions. Every three students in the experimental class are designated as a group. Students are entitled to discuss and chose the writing topic of the group, and then individual students determine their own writing titles. Then, according to the topic, students are encouraged to select and use particular strategies in this given context. For example, students are encouraged to use clear and idiomatic language, and transfer positively the writing skills in Chinese to their English writing, such as parallelism, rhetorical question, etc. At this stage, the students learn to analyze the writing task in hand, intentionally combine metacognitive strategies with writing practice. Meanwhile students can be stimulated since the topic and title are determined by students themselves, so students are more likely to actively devote to the writing task.

Secondly, to increases students' task knowledge by means of commenting on students' compositions. Students send their compositions entitled by themselves to one another within a study group and the teacher by E-mail. Every student will receive commentary from their classmates as well as the teacher. While commenting students' composition, the teacher provided external guidance by raising questions like "What do you mean by this sentence?" "Do you think this sentence is coherent with the theme of the essay?" and "What do you do if you are running out of ideas?" When the students think revision is needed, the teacher can offer clues like "What do you need to do to revise this sentence?" and "Do you need to delete it or add more sentences to make it coherent with the previous text?"

Group commentary (also peer commentary) enables students to present their views on a piece of writing just as a teacher does. It is a positive experience which helps students develop confidence in their own ability to write and find their advantages and disadvantages. The teacher commentary is of vital importance that provides students a persuasive rationale for strategy use. The outcome of this method is expected to further students' understanding of writing and develop students' knowledge of writing patterns.

Thirdly, to increase students' composing knowledge by a cognitive modeling think-aloud (Grabe \& Kaplan, 1996; Hartman, 2001). At the very beginning of performing a new task, the teachers provided students with a model essay to explain how to write a piece of English composition. Muchadopted teaching method is think-aloud. With the help of a computer and its connected projector, the teacher composes aloud in class in front of the students, by typing the words on the computer, which are projected to the big screen, so the whole class can follow the process of composing. While using the computer to write, the teacher verbally reports the ongoing mental activities that generate the written output. The class will observe the teacher's monologues like "What am I going to say next?" "Am I making my intended meaning clear to the readers?" "Should I delete this sentence to make the paragraph coherent?" and "What example can I provide to make the argument more persuasive?" The teacher's thinking-aloud to externalize the thought process thus serves as an expert model for the students to observe. By means of think-aloud, the teacher demonstrates to the students how to use the strategy in the writing process and makes them have a clear idea of the composing process and learn to orchestrate the use of more than one strategy in their writing practice. Undoubtedly, it is a tough job for teachers to compose by thinking aloud in class, so it is advisable that the teacher chooses some model essays and think aloud about the goals and mental processes involved so as to illustrate the use of metacognitive strategies.

To conclude, after this phase of training, students are supposed to improve their awareness of metacognitive strategy use and enrich their metacognitive knowledge as well as gradually apply appropriate strategy consciously in their writing.

c) Self-evaluation: This is a very important stage with an aim to develop students' self-regulatory ability, at which the teacher instructs students how to monitor and evaluate their writing processes and writing products.As Oxford (1990) points out, strategy training must provide students with a mechanism to evaluate their own progress as well as evaluate the success of the training and the value of the strategies in multiple tasks. The stage aims to develop students' ability to evaluate their strategy use and writing performance appropriately and systematically. The teacher regularly explains to the students whether using the strategy has proven helpful and what to do if it has not.

The present study has adapted Anderson's (2002) model to help students evaluate their strategy use by asking them to respond to the following questions which help students reflect through the cycle of learning: What am I trying to accomplish? --- Preparing and planning

What strategies am I using? -- Selecting and using particular strategies

How well am I using them? -- Monitoring strategy use

What else could I do? -- Orchestration of strategies

According to the model, a more detailed of strategy of self-monitoring has been introduced in the present study: A Self-Questioning Checklist, which can be used through the process of writing, is provided to the students by the teacher.

- At the beginning of writing. The Checklist covers the questions as follows:

What is the purpose of this essay?

What should be in the introductory paragraph?

How should I put these ideas in the best order?

According to the questions, students learn to make topic identification, information gathering, brainstorming and outlining and discuss the writing strategies which should be employed. Meanwhile they are instructed to create a map of additional ideas and conceptualize ways to order them, as it helps students capture their ideas before they are lost.

- While- and after-writing. In the process of writing, students think over the questions as follows:

Am I elaborating on all of my main points?

How clearly am I expressing my ideas? 
Am I making any spelling or grammar mistakes?

What was best about my paper?

Why did I make those spelling and grammar errors?

How can I best prevent those mistakes next time?

The above self-questions serve as a procedural facilitator to help students become aware of and think about their writing process in order to learn the effective writing strategies.

3) Expansion: This step is indispensable, since the metacognitive strategy training is comparatively new to the students and instructional input in class-time is relatively limited. It offers students opportunities to practice what has been taught and learned in class. As we all know, practice makes perfect. Without practice, students can't use the strategies flexibly and proficiently and nor will they understand the new approach deeply.

In the present study, the teacher assigns additional writing tasks related to in-class instruction and suitable for strategy practice as their homework. Students are asked to write a project on a topic, and also a commentary about their own project writing based on what they have learnt in class about writing. On each page of the homework they will turn in, the left-hand two thirds of the page contain the project writing and the right-hand margin is reserved for the commentary. And their grades are based both on the writing itself and the commentary. This activity explicitly requires students to reconsider what they have written i.e., to monitor their writing. Thus it aims to develop students' transfer of strategies to new tasks. Furthermore, asking students to comment on their own writing can further help them to evaluate their written products and lead them to adopt and develop corrective actions and compensatory strategies for future improvement.

\section{StUdents' AtTitude TOWARds Metacognitive STRATEGY INSTRUCTION}

Students' attitudes determine their choice of learning strategies (Wenden, 1987). So students' attitude is one of important factors to determine the effectiveness of the metacognitive strategy instruction. In order to see students' attitude towards the instruction, the present study has conducted a feedback questionnaire research at the end of the experiment. At the end of the experiment, the 42 students are asked to fill in a feedback questionnaire (see Appendix II) to examine whether the one-semester instruction has increased students' strategic ability or not. The results are shown in "Table I":

TABLE I. FEEDBACK TO METACOGNITIVE STRATEGY INSTRUCTION

\begin{tabular}{|c|l|l|l|l|l|l|}
\hline \multirow{2}{*}{$\begin{array}{c}\text { Metacognitive } \\
\text { strategies }\end{array}$} & \multicolumn{2}{c|}{ Improvement } & \multicolumn{2}{c|}{ Percentage } \\
\cline { 2 - 6 } & $\begin{array}{c}\text { Greatly } \\
\text { improvement }\end{array}$ & $\begin{array}{c}\text { Some } \\
\text { improvement }\end{array}$ & $\begin{array}{c}\text { No } \\
\text { improvement }\end{array}$ & $\begin{array}{c}\text { Worse } \\
\text { than past }\end{array}$ & $\begin{array}{c}\text { The first two } \\
\text { item }\end{array}$ & $\begin{array}{c}\text { The latter } \\
\text { two items }\end{array}$ \\
\hline Setting a goal & 13 & 16 & 12 & 1 & $70 \%$ & $30 \%$ \\
\hline Making a plan & 14 & 8 & 20 & 0 & $53 \%$ & $46 \%$ \\
\hline Monitoring & 20 & 16 & 5 & 1 & $86 \%$ & $14 \%$ \\
\hline Self-evaluation & 17 & 20 & 5 & 0 & $87 \%$ & $13 \%$ \\
\hline
\end{tabular}

Generally speaking, most of the students have positive attitude toward this instructional programme and think that they have made improvements in their metacognitive strategic ability. According to table 4.10 , over 30 students $(86 \%, 87 \%)$ believe that they have made great progress in using monitoring and evaluation strategies. It indicates that they have learnt to think more about their writing process and have had a strong strategic awareness of metacognition. The results also show that $70 \%$ students have made some improvements in setting a writing goal while $46 \%$ students think that they have not made any progress in planning strategies. Comparatively speaking, students do not do a good job in making any study plan and so more efforts need to be made to improve students' planning abilities.

To sum up, we can conclude that the metacognitive instruction is successful in general and has positive effects on students. The instruction has helped students to know more about the writing process and themselves as writers, which has enable them to set up a plan with a clear idea of writing purpose. All in all, the students made great progress in the metacognitive strategy use after receiving the instruction.

\section{CONCLUSION}

The metacognitive instruction should be integrated in the English class in order to improve students' metacognitive knowledge which can enlighten their thinking, and improve their abilities concerning planning, monitoring and regulating the learning process. Ample metacognitive knowledge enables students to apply appropriate strategies to monitor their writing process and products in order to achieve successful writing. Secondly, it is advisable to conduct the instruction right after students begin their college English learning because freshmen are more likely to encounter difficulties in their English writing among four grades of college students and have received the least instruction of learning strategies. Good beginning, half done. The early strategy instruction can ensure freshmen have a better understanding of metacognitive strategies, and help them develop more accurate metacognitive personal knowledge, task knowledge and strategy knowledge of writing, which will benefit their EFL writing as well as other aspects of English learning. Thirdly, when implementing the instruction, the instructor should carefully design the instructional activities and procedure. First of all, the instructor should arouse the non-English majors' interests in the strategy instruction. As we know, many non-English majors are passive English learners and they are not 
interested in English writing. So making them highly motivated is crucial for the success of the instruction. In order to motivate the students, a questionnaire can be employed. The instructor can use the questionnaire to make the students realize the importance of metacognitive strategy use and their metacognitive abilities. Next, the instructor can allow the students to determine the writing topic by group discussions, which undoubtedly will make students actively participate in the writing process and they are more likely to finish a successful composition since they are writing what they like. Then, the teacher can make some cue cards for the students to remind them to use the appropriate strategies while writing. Setting up a cognitive modeling can be another beneficial facilitator to gradually develop students' knowledge of metacognitive strategies. By setting up a cognitive modeling, the composing process is demonstrated clearly very clearly in front of the students. "Setting cognitive model is very beneficial for my writing. When teachers think out loud to externalize their thought processes serving as an "expert model', we can learn effective ways of using metacognitive knowledge and skills." Fourthly, the teacher plays a critical role in the classroom instruction. For one hand, the teacher should help students develop a positive attitude towards the classroom metacognitive instruction, and make them realize the importance and necessity of metacognitive strategy use. On the other hand, since different students have different writing proficiency, the teacher should give students' individual assistance according to her or his situation and help students find their own learning strategies based on their own strengths and weakness and gradually become independent writers. Meanwhile, the teacher should act as an assistant and coordinator and give students both written and oral evaluation on their writing products. In this process of evaluation, some positive comments are very helpful to stimulate students' interests in writing and build their writing confidence. Meanwhile, the instructor needs to be patient and considerate with his or her students throughout the whole instruction.

\section{REFERENCES}

[1] Anderson L W. Attitudes and their measurement. In T Husen \& T N Postlethwaite (Eds.), The International Encyclopedia of Education. Oxford: Pergamon, 1985, 1, 352-358.

[2] Anderson, N.J. The role of metacognition in second language teaching and learning. ERIC Digest. Education Resources Information Center, 2002.

[3] Baker, L. Brown, A. L. Metacognitive skills and reading. In P. D. Pearson (Ed.), Handbook of reading research. New York: Longman1984,353-394.

[4] Beach, R. Self-evaluation in an activity-oriented English classroom. The English Journal, 1975, 3, 59-63.

[5] Brown, A. L. Metacognitive development and reading. In R. J. Spiro, B. C. Bruce, \& W. F. Brewer (Eds.), Theoretical Issues in Reading Comprehension. Hillsdale, NJ: Lawrence Erlbaum Associates, 1980, 453-481.

[6] Brown, A. L. Metacognition, executive control, self-regulation and other more mysterious mechanisms. In F. E. Weinert \& R. H. Kluwe (Eds.), Metacognition, Motivation, and Understanding-Speculations about the Nature and Development of Metacognition. New Jersey: Lawrence Erlbaum Associates, 1987, 65-116.
[7] Chen, Huiyuan. Effects of task complexity and task condition on EFL writing. Modern Foreign Languages, 1998, 2, 49-54.

[8] Cohen, A. D. Strategies in Learning and Using a Second Language. London: Longman, 1998

[9] Cohen, A. D. Strategies in Learning and Using a Second Language. Beijing: Foreign Language Teaching and Research Press, 2000.

[10] Cohen, A. D., and Dornyei, Z. Focus on the language learner: Motivation, styles and strategies. In Schmitt, N. (Eds.), An Introduction to Applied Linguistics. London: Arnold, 2002,170-190.

[11] Devine, J. The role of metacognition in second language reading and writing. In J. G. Carson and I. Leki (Eds), Reading in the Composition Classroom: Second Language Perspectives. Boston: Heinle and Heinle, 1993, 105-127.

[12] Devine, J., Railey, K., and Boshoff, P. The implications of cognitive models in L1 and L2 writing. Journal of Second Language Writing, 1993, (2), 203-335.

[13] Ellis, R. (1985).Understanding Second Language Acquisition. Shanghai: Foreign Language Education Press, 1999.

[14] Ellis, R. (1994). The Study of Second Language Acquisition. Shanghai: Foreign Language Education Press, 1999.

[15] Eills, R. (1997). Second Language Acquisition. Shanghai: Foreign Language Education Press, 2000.

[16] Fang, Lingling, and Zhou, Rong, Study on "Length Approach" Teaching Method based on meta-cognitive strategy training, Improving Learning Proficiency through writing: Concept and operation of "Length Approach", Beijing: Science Press, 2004.

[17] Flavell, J. H. Metacognitive Aspect of Problem Solving. In L. B. Resnick (Eds.), The Nature of Intelligence. Hillsdale, NJ: Eribaum, 1976.

[18] Flavell, J. H. Metacognitive aspects of problem solving. In L. Resnick (Ed.).The Nature of Intelligence. Hillsdale, NJ: Erlbaum, 1979, 231236.

[19] Flavell, J. H. Metacognition and cognitive monitoring: A new area of cognitive-developmental inquiry. American Psychologist, 1979, 34, 906-911.

[20] Flavell, J. H. Speculations about the nature and development of metacognition. In F. E. Weinert \& R. H. Kluwe (Eds), Metacognition, Motivation, and Understanding - Speculations about the Nature and Development of Metacognition. New Jersey: Lawrence Erlbaum Associates, 1987, 21-29.

[21] Grabe, W., \& Kaplan, R.B. Theory and Practice of Writing. New York: Longman, 1996.

[22] Graham, S., and Harris, K.R. Students with learning disabilities and the process of writing: A meta-analysis of SRSD studies. In H. L. Swanson, K.R. Harris \& S. Graham (Eds.), Handbook of Learning Disability. New York: Guilford Press, 2003, 323-34.

[23] Hartman, H. J. Metacognition in teaching and learning: an introduction. Instructional Science, 1998, 26, 1-3.

[24] Hartman, H.J. Developing students' metacognitive knowledge and skills. In H.J. Hartman (Eds.), Metacognition in Learning and Instruction:Theory, Research and Practice. Boston: Kluwer Academic, 2001, 33-68.

[25] Jacobs, J. E., and Paris, S. G. Children's metacognition about reading: issues in definition, measurement, and instruction. Educational Psychologist, 1987, 22, 255-278.

[26] Ji, Kangli., Metacognitive Strategy Training in Foreign Langugages. The Territories of Foreign Languages, 2002, 2 , 20-26.

[27] Tang, Zhenghua. , Study on Metacognitive Strategy of English Writing in Senior Middle School. Selection of Excellent Thesis, 2001.

[28] Kasper, L. F. Assessing the Metacognitive Growth of ESL Students Writers. TESL-EJ, 1997, 3 (1), 1-20.

[29] Lu, Wenjun. , Metacognitive Strategy and English Writing. Foreign Languages and Foreign Language Writing, 2006, 9, 25-27.

[30] Ma, Guanghui, and Wen, Qiufang, Factors Influencing College English Writing, Journal of Foreign Language Teaching and Research, 1999, 4, 34-39. 
[31] Nunan, D. (1992). Research Methods in LanguageLearning. Cambridge: Cambridge University Press, 2001.

[32] OlMalley, J. M., Chamot, A. U., etc. Learning Strategies Used by Beginning and Intermediate ESL students. Language Learning, 1985, 35(1), 21-46.

[33] O'Malley, J. M., \& Chamot, A. U. (1990). Learning Strategies in Second Language Acquisition. Shanghai: Shanghai Foreign Language Education Press, 2001.

[34] Oxford, R. Use of Language Learning Strategies: A Synthesis of Studies With Implications for Strategy Training, System, 1989, 17, 235-247.

[35] Oxford, R. Language Learning Strategies: What Every Teacher Should Know [M]. New York: Newbury House Publishers, 1990.

[36] Paris, S. G. and Winograd, P. How metacognition can promote academic learning and instruction [A]. In B. F. Jones and L. Idol (Eds.), Dimensions of Thinking and Cognitive Instruction [C]. Hinsdale, NJ: Lawrence Erlbaum Associates, 1990.

[37] Porte, G. 1988. Poor Dealing with New Language Learners and Their Strategies for Vacabulary. ELT Journal, 42 (3), 167-172.

[38] Rubin, J. What the "Good Language Learners" Can Teach Us. TESOL Quarterly. 1975, 9, 41-51.

[39] Rivers, W. Autonomy at all costs: An Ethnography of Metacognitive Self-assessment and Self-management among Experienced LanguageLearners. Journal of the Modern Language, 2001, 85 (2), 279-290.

[40] Schraw, G. Promoting General Metacognitive Awareness. In H. J. Hartman (Ed.), Metacognition in Learning and Instruction: Theory, Research and Practice. Netherlands: Kluwer Academic Publishers, 2001, 3-16.

[41] Stern, H. (1983). Fundamental Concepts of Language Teaching. Shanghai: Shanghai Foreign Language Education Press, 1999, 405.

[42] Tang, Fang, and Xu, Jinfen. Survey of English Writing Metacognition Research at Home and Abroad, Journal of Foreign Languages Territories, 2005, 5, 18-23.

[43] Vann, R. J. and Abraham, R. G. 1990 Strategies of Unsuccessful Language Learners. TESOL Quarterly, 24(2), 177-197.

[44] Victori, M. An Analysis of Writing Knowledge in EFL Composing: A Case Study of Two Effective and Two Less Effective Writers. System, 27, 1999: 537-555.

[45] Vygotsky, L. Mind in society. Cambridge, MA: Harvard University Press, 1978.

[46] Wang, Chuming, et al., Improving Learning Proficiency by Writing - Experimental Research on English Writing. Journal of Foreign Language Teaching and Research, 2000, 3, 207-212.

[47] Wang, Wenyu, and Wen, Qiufang, Native Language Thinking and the Second Language Writing. Journal of PLA Foreign Languages Institute, 2002, 4, 64-67.

[48] Weinstein, C. and Mayer R. The teaching of learning strategies. In Merlin C. W. (Ed), Handbook of Research on Teaching. New York: Macmillan, 1986: 315

[49] Wenden, A. and Rubin, J. Learner Strategies in Language Learning [M]. London: Prentice Hall International, 1987.

[50] Wen, Qiufang, On English Learning Strategies. Shanghai: Shanghai Foreign Language Education Press, 1996.

[51] Wen, Qiufang], Changing Tendency and Characteristics of College Students' Learning Strategies. Foreign Language Teaching and Research, 1996, 4, 43-46.

[52] Wen, Qiufang, and Wang, Haixiao, English Learning beliefs and Strategies of College Students. Journal of PLA Foreign Languages Institute, 1996, 4, 61-75.

[53] Wenden, A. An introduction to metacognitive knowledge and beliefs in language learning: Beyond the basics. System, 1999, 27, 435-441.

[54] Wu, Hongyun, An Empirical Study of Metacognitive Theory in Second Language Writing, Beijing: Foreign Language Teaching and Research Press, 2006.

[55] Wu, Hongyun. A longitudinal study on metacognition in EFL Writing of Chinese University Students. CELEA Journal, 2008 ,4, 87-91.
[56] Wu, Hongyun, and Liu, Runqing, Factors Analysis of Metacognition Theory in Second Language Writing. Foreign Language Teaching and Research Press, 2004, 3, 187-193.

[57] Wu, Jin, and Zhang, Zaixin, New Exploration of English Writing Teaching. Journal of Foreign Language Teaching and Research, 2000 3, 213-218.

[58] Yuehai, Xiao, Applying metacognition in EFL writing instruction in China. Reflections on English Language Teaching, 2008, 6, 19-33.

[59] Zhao, Yongqing, On English Teaching from Perspective of the Discourse Patterns. Journal of Modern Languages, 1995, 2, 25-30.

[60] Zhu, Ye, On Learning Strategies Training. Selection of Excellent Thesis, 2007 